\title{
THE INORGANIC CONSTITUTION OF MOLLUSCAN BLOOD AND MUSCLE
}

\author{
By F. R. Hayes and D. Pelluet \\ From the Plymouth Laboratory and the Zoological Laboratory, \\ Dalhousie University, Halifax, Nova Scotia
}

\begin{tabular}{|c|c|c|c|c|c|c|c|c|}
\hline \multicolumn{9}{|c|}{ CONTENTS } \\
\hline \multirow{6}{*}{$\begin{array}{l}\text { Introduction } \\
\text { Samples for Analysis } \\
\text { Treatment of Samples } \\
\text { Previous Analyses } \\
\text { Blood of Marine Forms }\end{array}$} & & PAGE & & & & & & PAGE \\
\hline & . & . 580 & Muscle of 1 & in & iorms & & & 584 \\
\hline & . & . $\quad 580$ & The Fresh- & er & $\mathrm{am}$ & . & . & 586 \\
\hline & . & 582 & Summary & . & . & : & : & 587 \\
\hline & . & . $\quad 582$ & References & . & . & & . & 588 \\
\hline & . & . $\quad 584$ & & & & & & \\
\hline
\end{tabular}

\section{INTRODUCTION}

A good many papers have been published in recent years leading to the conclusion that mammalian tissues can be viewed as composed of separate phases, corresponding approximately to cells and intercellular spaces, which differ in their inorganic composition. The technique has been to analyse the tissue as a whole and, by comparison with serum analyses, to calculate the space occupied by the cells and their constitution. Direct histological work provides additional evidence on the proportion of a tissue accounted for as cells.

It appeared desirable to extend this type of work to another phylum, and the Mollusca were selected because of possible future opportunities to compare related terrestrial, aquatic and marine forms, such as are found among the Gastropoda. The Mollusca also show an excellent fossil record, so that they might be expected to provide opportunity to test out the idea that land animals carry with them some record of the constitution of the ocean at the time they left it. We have not yet had an opportunity to extend our analyses to those gastropods that have left the sea, but the present results on marine forms provide a basis for such a study. The single fresh-water species used was a clam, and it did not exhibit any peculiarities that could be said to reflect the presumed composition of the ocean in earlier times.

\section{SAMPLES FOR ANALYSIS}

Specimens of Anodonta were brought to Plymouth and maintained there in fresh water. Pecten, Aplysia, Buccinum, Eledone, Eusepia, and Loligo forbesi were taken near Plymouth and maintained in aquarium water, which was sea water to which had been added $25 \%$ extra calcium. Mactra, Busycon and Loligo pealii were collected near Woods Hole and maintained in sea water there. 
To obtain blood from Anodonta or Mactra a hole was cut in the shell (Anodonta) or the hinge muscle was sliced to allow the clam to open (Mactra) and a cannula ligatured into one end of the exposed heart. The animals being kept under water, the heart continued to beat until up to $25 \mathrm{ml}$. of blood (Anodonta) or $60 \mathrm{ml}$. (Mactra) were pumped out. As the blood pressure was low the flow was assisted by making the collecting tube serve as a siphon. With Pecten the procedure was to remove an individual from water and, when the shell gaped naturally, to keep it open by inserting a cork. The animal was then held hinge uppermost and the sea water inside drained and blotted away. The blood bulged into sinuses by the hinge muscle and edges of the mantle between the eyes, so that an incision could be made with fine scissors, allowing 6-8 ml. of blood to flow out at once.

Aplysia blood was obtained simply by opening the dorsal body wall, care being taken not to contaminate the sample with mucus. To secure Buccinum and Busycon blood samples, a cord was tied under the operculum, a little of the shell chipped away, and the foot pulled out somewhat. Adherent sea water was dried off and a cut made under the foot with a razor blade, which permitted $25 \mathrm{ml}$. of blood to gush out from the pedal sinus of Busycon, or 6-8 ml. from Buccinum.

With cephalopods the animal was first nailed to a board through its tentacles with the ventral side up (Eusepia, Loligo) or the dorsal side up (Eledone). The mantle was then slit open exposing a prominent blood vessel (vena cava in Eusepia and Loligo; aorta in Eledone). Into this a cannula was ligatured and connected to a collecting flask. The board and flask were immersed in a tank, the system being completely closed except for a tube extending from the flask above the surface, through which a gentle suction could be applied to start the blood flow. The flask was at a lower level than the animal, so that the collecting tube could act as a siphon. If the operation were completed quickly the Eledone or Eusepia soon began to respire and pumped $50 \mathrm{ml}$. or more of blood into the flask. Specimens of Loligo forbesi failed to yield sufficient blood for analysis, either by the above technique or others tried. With Loligo pealii up to Io $\mathrm{ml}$. of blood could be obtained from a specimen before respiratory movements ceased. Dr Z. M. Bacq kindly showed us how to carry out several of the foregoing techniques.

For tissue analyses the main hinge muscle was taken from Pelecypoda, foot muscle from Gastropoda, and mantle muscle from Cephalopoda. The muscle was freed from any other tissue and in the gastropod foot, the pedal sinus was exposed and drained before the tissue was analysed. In Aplysia the foot muscle was so spongy that it was difficult to cut away surface tissue cleanly or to blot up adherent water in a uniform manner; the physical appearance suggested that intercellular space occupied a large proportion of the muscle, an idea borne out by the analyses. 


\section{Treatment of SAmples}

To estimate water content a known volume of blood, or weight of muscle, was dried at $100^{\circ} \mathrm{C}$. For determination of base the samples taken at Plymouth were ashed at $400^{\circ} \mathrm{C}$. and dissolved in acid. In Woods Hole they were extracted with boiling water in a Soxhlet apparatus and the protein precipitated with trichloracetic acid or uranium acetate (the latter not very satisfactory).

Sodium was estimated by the method of Ball \& Sadusk (I936). The method followed for potassium was that of $\mathrm{Kramer}$ (1920). For magnesium the method used was that of Greenberg et al. (1932, 1935). Calcium was precipitated as oxalate, and finally estimated either by the gasometric method given in Peters \& van Slyke (1932, p. 425), or according to Larson \& Greenberg (I938). A specially ashed sample was used for each chloride determination, following van Slyke (1923-4). Special ashing with the Benedict-Denis reagent was also resorted to for some of the sulphate tests, others being done on the Soxhlet extracts. The sulphate in the extracts was titrated with barium chloride using either sodium rhodizonate (Robertson \& Webb, 1939) or tetrahydroxyquinone (Sheen \& Kahler, 1936) as an indicator. We have also tried the benzidine method of Fiske (I92I). Results on blood sulphur were fair, but those on muscle are not good enough to publish.

The muscle samples were weighed, hence the analytical results came out directly as per cent by weight. Blood samples however, were taken by volume so that the results in the first instance appeared as $\mathrm{g}$./ $100 \mathrm{ml}$. blood, that is as per cent $\mathrm{w} / \mathrm{v}$. In order to express the blood results gravimetrically they were multiplied by the factor 0.974 , which is the volume occupied by I $\mathrm{g}$. of sea water at $17.5^{\circ} \mathrm{C}$. Thus all figures in Table I are in per cent by weight. (No factor was applied to Anodonta blood which was found to have practically the same density as distilled water.)

The ultimate analytical standard was a sample of Copenhagen sea water of known chlorinity, from the laboratory of Prof. Knudsen. From the chloride the concentration of the other ions was calculated, assuming the relative strengths as given in Dittmar's classical figures. The sample was subjected to repeated analyses and appropriate factors derived for our reagents, which were used in subsequent blood and muscle tests.

\section{Previous ANALYSES}

In Table I there have been included some analyses from the literature which appear to be directly comparable with our own. Values have, where necessary, been recalculated to make them read per cent by weight, using for marine blood, the factor given above. A word might be said about some analyses not quoted in the table. 
Table I. Mineral Constitution of Molluscan Blood and Muscle

All values are in $\mathrm{g} . / \mathrm{IOO} \mathrm{g}$. Where no reference is given on the right, the analyses are our own Blood Muscle

\begin{tabular}{|c|c|c|c|c|c|c|c|c|c|c|c|c|c|c|}
\hline & \multicolumn{7}{|c|}{ Blood } & \multicolumn{6}{|c|}{$\underbrace{\text { Muscle }}$} & \multirow[b]{2}{*}{ Reference } \\
\hline & Water & $\mathrm{Na}$ & $\mathrm{K}$ & $\mathrm{Ca}$ & $\mathrm{Mg}$ & $\mathrm{Cl}$ & $\mathrm{SO}_{4}$ & Water & $\mathrm{Na}$ & $\mathrm{K}$ & $\mathrm{Ca}$ & $\mathrm{Mg}$ & $\mathrm{Cl}$ & \\
\hline Plymouth sea water & $97 \cdot 4$ & $\mathrm{I} \cdot 097$ & 0.0388 & 0.0428 & 0.134 & I.967 & 0.274 & - & - & - & - & - & - & - \\
\hline $\begin{array}{l}\text { Plymouth aquarium } \\
\text { water }\end{array}$ & ד & - & - & 0.0531 & - & - & - & 一 & - & - & - & - & - & 一 \\
\hline Woods Hole sea water & $97 \cdot 4$ & - & - & 一 & 0.109 & $\mathrm{I} \cdot 86$ & 0.286 & - & 一 & - & - & - & - & - \\
\hline $\begin{array}{l}\text { Pelecypoda: } \\
\text { Mactra solidissima }\end{array}$ & - & - & - & - & & & & & - & -1 & & & & - \\
\hline Mytilus edulis & - & $\mathrm{I} \cdot 009$ & $0.034 \mathrm{I}$ & 0.0448 & $0.115^{\star}$ & $\begin{array}{l}\mathbf{I} \cdot 77 \\
\mathbf{I} \cdot 87\end{array}$ & $\underline{0.266}$ & - & - & - & - & $\underline{0.0249}$ & $\underline{0.243}$ & $\begin{array}{l}\text { Bethe \& Berger (I93I), } \\
\star \text { Krogh (I939) }\end{array}$ \\
\hline M. edulis & 一 & - & - & - & - & - & - & - & 0.110 & 0.369 & $0 \cdot 1020$ & 0.0210 & - & $\begin{array}{l}\text { Bialaszewicz \& Kupfer } \\
\text { (I936) }\end{array}$ \\
\hline $\begin{array}{l}\text { Ostrea circumpicta } \\
\text { Pecten maximus }\end{array}$ & $95 \cdot 9$ & $I \cdot 160$ & 0353 & 0.0414 & 0.149 & 2.05 & 0.275 & - & - & - & - & - . & - & Kumano (1929) \\
\hline $\begin{array}{l}\text { Pecten maximus } \\
\text { Pinna nobilis }\end{array}$ & $\underline{96 \cdot 4}$ & $\underline{I \cdot 094}$ & $\begin{array}{l}0.0514 \\
0.0630\end{array}$ & $\begin{array}{l}0.0540 \\
0.0590\end{array}$ & $\begin{array}{l}0.105 \\
0.140\end{array}$ & $\begin{array}{l}1 \cdot 92 \\
2 \cdot 20\end{array}$ & $\begin{array}{l}0.282 \\
0.285\end{array}$ & $\stackrel{80 \cdot 7}{-}$ & $\underline{0.112}$ & $\underline{0.439}$ & 0.0112 & 0.0081 & $\underline{0.190}$ & Bialaszewicz (I933) \\
\hline Gastropoda: & & & & & & & & & & & & & & \\
\hline $\begin{array}{l}\text { Aplysia punctata } \\
\text { Buccinum undatum }\end{array}$ & - & $\begin{array}{l}1 \cdot 130 \\
0.052\end{array}$ & 0.0382 & $\begin{array}{l}0.0535 \\
0.0427\end{array}$ & $\begin{array}{l}-19 \\
0.119 \\
0.102\end{array}$ & I.92 & 0.282 & $85 \cdot 5$ & 0.751 & 0.187 & 0.0670 & 0.2320 & I.34 & - \\
\hline $\begin{array}{l}\text { Buccinum undatum } \\
\text { B. undatum }\end{array}$ & - & 0.952 & 0.0301 & $\underline{0.0427}$ & $\stackrel{0.102}{-}$ & $\overline{\mathrm{I} \cdot 88}$ & 0.249 & - & $\underline{0.144}$ & 0.325 & 0.0315 & 0.0860 & $\underline{431}$ & Duval (1925) \\
\hline Busycon canaliculata & - & - & - & - & 0.103 & I. 68 & 0.285 & - & - & - & - & 0.0647 & 0.306 & \\
\hline Do & - & $I \cdot I 49$ & 0.0572 & $0.049 \mathrm{I}$ & 0.135 & $\mathrm{I} \cdot 84$ & - & - & $\div$ & - & - & - & 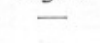 & Bethe \& Berger (I93I) \\
\hline $\begin{array}{l}\text { Cephalopoda } \\
\text { Eledone cirr }\end{array}$ & & & & & & & & & & & & & & \\
\hline $\begin{array}{l}\text { Eledone cirrosa } \\
\text { Eusepia officinalis }\end{array}$ & $\overline{95.5}$ & $\begin{array}{l}0.979 \\
\mathrm{I} \cdot 048\end{array}$ & $\begin{array}{l}0.0473 \\
0.0450\end{array}$ & $\begin{array}{l}0.0467 \\
0.0480\end{array}$ & $\begin{array}{l}0.139 \\
0.125\end{array}$ & $\begin{array}{l}\mathrm{I} \cdot 68 \\
\mathrm{I} \cdot 85\end{array}$ & $\begin{array}{l}0.414 \\
0.277\end{array}$ & $\overline{80 \cdot 4}$ & $\begin{array}{l}0 \cdot 186 \\
0 \cdot 198\end{array}$ & $\begin{array}{l}0.403 \\
0.398\end{array}$ & $\begin{array}{l}0.0146 \\
0.0083\end{array}$ & $\begin{array}{l}0.0310 \\
0.0085\end{array}$ & $\begin{array}{l}0.325 \\
0.360\end{array}$ & - \\
\hline 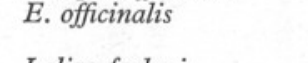 & & & & & & & & & 0.180 & 0.775 & 0.0335 & $0.056 I$ & & $\begin{array}{l}\text { Bialaszewicz \& Kupfer } \\
(1936)\end{array}$ \\
\hline $\begin{array}{l}\text { Loligo forbesi } \\
\text { L. pealii }\end{array}$ & - & - & - & 0.0390 & $\overline{0.100}$ & $\begin{array}{l}\text { I.94 } \\
\text { I. } 67\end{array}$ & 0.271 & 83.9 & 0.156 & 0.383 & 0.0051 & $0 . \overline{0146}$ & 0.221 & - \\
\hline L. pealii & - & 0.815 & 0.0650 & - & - & I. 66 & 一 & $77 \cdot 6$ & 0.123 & 0.444 & - & 0.014 & $\begin{array}{l}0.223 \\
0.252\end{array}$ & Manery (I939) \\
\hline L. 2 & & & (2) & 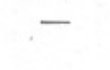 & 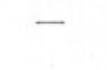 & 200 & & 170 & 0.155 & 0.742 & 0.0260 & 0.0480 & $=2$ & $\begin{array}{l}\text { Bialaszewicz \& Kupfer } \\
\text { (1936) }\end{array}$ \\
\hline $\begin{array}{l}\text { Pelecypoda, fresh- } \\
\text { Anodonta cygnea }\end{array}$ & 99.8 & 0.0356 & 0.00155 & 0.0212 & 0.000 & 02 & 700.0 & 9 & 0.0119 & 0.0413 & 30.0215 & 97 & 0.0370 & - \\
\hline
\end{tabular}


Griffiths (I89I, I892) made estimations on the blood of a dozen molluscs, together with many other invertebrates. His figures provide the first demonstration that the blood is in a general way similar in composition to sea water.

There are several analyses of chloride in blood by Duval (1925) which are very like our own. The one on Buccinum is quoted in Table I.

Myers (1920) reports an extraordinary concentration of calcium in the blood of Schizotherus nuttalli. In view of his method of collection the purity of the sample is open to doubt. He states that 'the exposed body of the clam was superficially cut in several places and then gently macerated. The liquid collected was filtered through loose cotton.'

McCance \& Shipp (1933-4) give values for the four bases in the muscle of Cardium edule. The results fall clearly between our figures for blood and muscle. They state 'that the magnesium, sodium and water tend to vary together', and that 'the potassium concentration in the various organs of these invertebrates runs parallel not with the water but with the dry matter'. It is a fair deduction, in the light of our results, that McCance \& Shipp were dealing with muscle containing a good deal of adherent blood or sea water.

Singh (1937-8) has done sodium, potassium and chloride in Mytilus blood and muscle, the results on muscle, like those of McCance \& Shipp, falling between our blood and muscle values, probably for the same reason.

\section{BLOOD OF MARINE Forms}

On averaging the results of Table I and taking the scatter into account, the following conclusions may be drawn. The concentrations of sodium and potassium in pelecypod and gastropod blood cannot be shown to differ from those of sea water; in the Cephalopoda sodium appears to be a little lower and potassium a little higher than in sea water. In all three classes calcium is higher and magnesium lower than in the sea. It is known (Collip, I920) that bivalves, on being kept in the air as between tides, show a marked rise in blood calcium, and sometimes a slighter rise of magnesium. It is likely in such instances that an accumulation of carbonic and lactic acids reacts with calcium from the shell (Dugal, 1939; Culbreth, I94I). Blood chloride in the Pelecypoda cannot be shown to differ in concentration from that of the sea; in the other two groups, especially Cephalopoda, it is hypotonic to sea water. Krogh (1939, p. 56) has a table leading to the same conclusion. As regards sulphate no concentration differences between outer and inner media are seen. In summary, the cephalopods show regulatory powers with respect to five of the six ions under consideration, the gastropods three, and the bivalves two.

\section{MusCle OF MARINe Forms}

The quantities of the ions in muscle are quite different from those in blood and appear to follow the same pattern in the three classes. The concentration ratios of muscle to blood are approximately: sodium I/IO to I/5, potassium 
IO/I according to our results, but $20 / \mathrm{I}$ in cephalopod muscle according to Bialaszewicz \& Kupfer (1936), calcium I/4 to $3 / 4$, magnesium I/Io to $2 / 3$, chloride I/IO to I/5. The above estimate leaves Aplysia out of account, for the analyses suggest that in this genus there is a great deal of blood mixed in with the cells, while the foot appears on dissection as a loose network of fibres quite different from the compact muscle mass obtained from other molluscs.

Expressed as milliequivalents per $\mathrm{kg}$. of water, the decrease in sodium from blood to muscle amounts to about 400, to which are added smaller losses of calcium and magnesium. Against this the gain in potassium is only about roo. It follows that in so far as these bases are concerned, muscle will be markedly hypotonic to blood. Isotonicity is apparently brought about by small organic molecules such as taurin (Kelly, cited by Krogh, 1939, p. 57).

The marked differences between blood and muscle salts suggest that muscle might be considered in two phases, an intercellular blood space containing all the sodium chloride, and a cell space. The intercellular space, $i$, is obtained, as a per cent of the whole muscle by the formula

$$
i=\frac{\% \mathrm{Na}(\text { or } \mathrm{Cl}) \text { in muscle } \times \mathrm{I00}}{\% \mathrm{Na}(\text { or } \mathrm{Cl}) \text { in blood }},
$$

application of which to several genera is given in the left-hand columns of Table II. The averages are I8.I \% intercellular space for gastropod-cephalopod blood and 10.9\% for pelecypod space. Singh (1937-8) gives higher results of 20-30\% for Mytilus, but his specimens were out of water for some hours prior to analysis, which might account for a difference.

Table II. Per Cent of Muscle Occupied by Intercellular Space and CONCENTRATION OF IONS WITHIN THE CELLS

\begin{tabular}{|c|c|c|c|c|c|}
\hline \multirow[t]{2}{*}{ Genus } & \multicolumn{2}{|c|}{$\begin{array}{l}\text { Intercellular space } \% \text {. } \\
\text { Calculated from }\end{array}$} & \multicolumn{3}{|c|}{$\begin{array}{l}\text { Constitution of cells, \% of wet weight } \\
(\mathrm{Na} \text { and } \mathrm{Cl} \text { being taken as zero) }\end{array}$} \\
\hline & $\mathrm{Na}$ & $\mathrm{Cl}$ & $\mathrm{K}$ & $\mathrm{Ca}$ & $\mathrm{Mg}$ \\
\hline Mactra & - & I3.7 & - & - & 0.0 II \\
\hline Mytilus & 10.0 & 1 & $0.4 \mathrm{I}$ & $0.1 \mathrm{I}$ & 0.010 \\
\hline Pecten & 10.2 & 9.8 & 0.48 & 0.0064 & -0.003 \\
\hline Buccinum & I5. I & 22.9 & 0.39 & $0.38^{4}$ & 0.083 \\
\hline Busycon & - & I $8 \cdot 2$ & - & - & 0.056 \\
\hline Eledone & 19.0 & I9. 4 & 0.39 & -0.090 & 0.005 \\
\hline Eusepia & 18.0 & I9. 4 & 0.48 & -0.007 & -0.018 \\
\hline Loligo & $\mathrm{I} 7 \cdot 8$ & $13 \cdot 2$ & 0.45 & -0.002 & -0.004 \\
\hline
\end{tabular}

By making use of the intercellular space value derived as above described, one is able to estimate the quantities of potassium, calcium and magnesium in the cells themselves by use of the formula

$i \times \%$ of ion in blood $+(\mathrm{IO0}-i) x=\mathrm{I00} \times \%$ of ion in whole muscle, where $i$ is the intercellular space and $x$ is the per cent of the ion in muscle cells. The application of the formula gives values which are set down in the righthand columns of Table II. Pelecypod and cephalopod cells appear to be alike 
and to contain, within the limits of error, $\mathrm{K} 0.44 \%$, Ca none, $\mathrm{Mg}$ none. The Gastropoda, on the inadequate evidence presented, have $\mathrm{K}$ as in other groups, together with appreciable amounts of $\mathrm{Ca}$ and $\mathrm{Mg}$. It may be that the difference between the groups is due to the presence of inactive precipitates of calcium and magnesium in gastropods, such as McCance \& Masters (1937) report in Archidoris. We are thus led to the general conclusion that, of the ions under consideration, the cells themselves may contain only potassium.

The analyses of Bialaszewicz \& Kupfer (1936) on cephalopod muscle give values for potassium, calcium and magnesium that are two or three times as high as ours (Table I) and which lead, on calculation, to the conclusion that considerable amounts of all three substances are present in the cells. The contradiction between their results and ours cannot be explained at present.

\section{The Fresh-water Clam}

Table I has analyses of Anodonta blood and muscle, whose values in general are much lower than those of marine forms; in fact fresh-water clams are said to have a lower proportion of solids in their blood than any other animal. A comparison of Anodonta blood with marine fluids is facilitated if sodium be assigned a value of 100 and other ions calculated in proportion. This is done in Table III which shows that Anodonta blood is characterized by a large quantity of calcium and a lack of sufficient chloride to neutralize the sodium.

Table III. Anodonta Blood Compared to Sea Water, in Each Assigning Sodium a Value of ioo

Figures in brackets are those of de Waele (1930)

$\begin{array}{lcc}\text { Ion } & \text { Sea water } & \text { Anodonta } \text { blood } \\ \mathrm{Na} & 100 & 100 \\ \mathrm{~K} & 4 & 4(7) \\ \mathrm{Ca} & 4 & 59 \\ \mathrm{Mg} & \mathrm{I} 2 & 2(6) \\ \mathrm{Cl} & 180 & 104 \\ \mathrm{SO}_{4} & 25 & 4 \mathrm{I}\end{array}$

Investigation would doubtless reveal enough bicarbonate to account for most of the excess base. The figures in brackets are those of de Waele (1930), which have been included only in places where his results differ materially from ours. An analysis of sodium and calcium in the blood of four genera of fresh-water clams by Ellis et al. (1930) is in general agreement with our results.

Turning to muscle, one may treat the values in Table I as was done for marine forms, i.e. assume two phases, cells and blood, which differ in constitution, and attempt to find the space occupied by each. The only element that can be used for such a computation is sodium, since it is the only ion found in higher concentration in blood than in muscle. From Table I we obtain

$$
\text { Na space }=\frac{0.0119 \times 100}{0.356}=33 \%
$$


From this the constitution of a muscle cell may be obtained as already described, and works out as follows in per cent: Na none (assumed), $\mathrm{K}$ 0.06I, $\mathrm{Ca} 0.022, \mathrm{Mg} 0.0085, \mathrm{Cl} 0.037$. Potassium is clearly the dominant ion but other base is present as well, and there is a considerable quantity of chloride. Expressed in other terms, the above base sums up to 3.4 milliequivalents, while the chloride amounts to only I $\circ 0$ milliequivalent, so that unless most of the base is osmotically inactive, some additional acid must be present, probably largely bicarbonate. As might be expected the cells are markedly hypotonic to those of marine forms, the dominant ion, potassium, being only one-seventh as concentrated.

\section{SUMMARY}

Estimations of sodium, potassium, calcium, magnesium, chloride and sulphate have been made on the blood and muscle of marine molluscs and of the freshwater clam, Anodonta.

On comparing marine blood with sea water it appears that the cephalopods show a regulatory power (i.e. difference between blood and sea water) with respect to all ions tested except sulphate. The gastropods have a regulatory power for calcium, magnesium and chloride; the pelecypods for calcium and magnesium.

Calcium is always higher in blood than in sea water, while magnesium is lower. Chloride, where it differs, is lower.

If muscle is considered as two phases, cells and intercellular blood space, then from whole muscle and blood analyses it is possible to calculate the spaces between the cells, which work out at II $\%$ for pelecypods and I $8 \%$ for the other two groups. Further calculation gives the constitution of the cells themselves, leading to the conclusion that, of the ions under consideration, only $\mathrm{K}$ is present in the Pelecypoda and Cephalopoda, while the Gastropoda may have some $\mathrm{Ca}$ and $\mathrm{Mg}$ as well as $\mathrm{K}$.

As expected the fresh-water clam contains little inorganic material. In relative proportions its blood is characterized by more calcium and less magnesium and chloride than that of marine forms. In muscle cells potassium dominates but other ions are present as well.

This work was carried out at the Laboratory of the Marine Biological Association, Plymouth, in the summers of 1936 and 1937, and at the Oceanographic Institution, Woods Hole, in 1939. It is a pleasure to express our thanks to the Directors and Staffs of these establishments for accommodation, facilities and advice during the progress of the investigation. 


\section{REFERENCES}

BALl, E. G. \& SADUSK, J. F., Jr., I936. A study of the estimation of sodium in blood serum. Fourn. Biol. Chem., Vol. Ir3, pp. 66I-74.

BETHE, A. \& BERGER, E., I93I. Variationen im Mineralbestand verschiedener Blutarten. Pflügers Arch. ges. Physiol., Bd. 227, pp. 571-84.

Bialaszewicz, K., I933. Contribution à l'étude de la composition minérale des liquides nourriciers chez les animaux marins. Arch. Internat. Physiol., T. 36, pp. 4I-53.

Bialaszewicz, K. \& Kupfer, Ch., I936. De la composition minérale des muscles des animaux marins. Arch. Internat. Physiol., T. 42, pp. 398-404.

Collip, J. B., I920. Studies on molluscan celomic fluid. Effect of change in environment on the carbon dioxide content of the celomic fluid. Anaerobic respiration in Mya arenaria. Fourn. Biol. Chem., Vol. 45, pp. 23-49.

Culbreth, S. E., I94I. The role of tissues in the anaerobic metabolism of the mussel, Anodonta hallenbeckii Lea. Biol. Bull., Vol. 80, pp. 79-85.

Dugal, L-P., I939. The use of calcareous shell to buffer the product of anaerobic glycolysis in Venus mercenaria. Fourn. Cell. Comp. Physiol., Vol. I3, pp. 235-5 I.

Duval, M., I925. Recherches physico-chimiques et physiologiques sur le milieu intérieur des animaux aquatiques. Modifications sous l'influence du milieu extérieur. Ann. Inst. Océanograph., T. 2, pp. 232-407.

Ellis, M. M., Merrick, A. D. \& Ellis, M. D., I930 (I93I). The blood of North American fresh-water mussels under normal and adverse conditions. Bull. U.S. Bur. Fisheries, Vol. 46, pp. 509-42.

FISKE, C. H., I92I. The determination of inorganic sulfate, total sulfate, and total sulfur in urine by the benzidine method. Fourn. Biol. Chem., Vol. 47, pp. 59-68.

GreENBERG, D. M., ANDERson, C. \& TufTs, E. V., I935. A note on a closed titration flask for use in the bromometric determination of magnesium with 8-hydroxyquinoline. Fourn. Biol. Chem., Vol. II I, pp. 56I-5.

GreENBerG, D. M. \& MACKeY, M. A., I932. The determination of magnesium in blood with 8-hydroxyquinoline. Fourn. Biol. Chem., Vol. 96, pp. 4I9-29.

Griffiths, A. B., I891. On the blood of the Invertebrata. Proc. Roy. Soc. Edin., Vol. I8, pp. 288-94.

— I892. On the blood of the Invertebrata. Proc. Roy. Soc. Edin., Vol. I9, pp. II6-30.

KRAMER, B., I920. Direct quantitative determination of potassium and sodium in small quantities of blood. Fourn. Biol. Chem., Vol. 4I, pp. 263-74.

Krogh, A., 1939. Osmotic Regulation in Aquatic Animals. Cambridge.

Kumano, M., I929. Chemical analysis on the pericardial fluid and the blood of Ostrea circumpicta Pils. Sci. Rep. Tôhoku Imp. Univ., Ser. IV, Vol. 4, pp. 28I-4.

LARSON, C. E. \& GREENBERG, D. M., I938. The analysis of calcium in blood and other biological material by titration with ceric sulphate. Fourn. Biol. Chem., Vol. I23, pp. I99-20I.

MCCANCE, R. A. \& MASTERs, M., I937. The chemical composition and the acid-base balance of Archidoris britannica. Fourn. Mar. Biol. Assoc., Vol. 22, pp. 273-9.

McCance, R. A. \& ShIpp, H. L., I933-4. The magnesium and other inorganic constituents of some marine invertebrates. Fourn. Mar. Biol. Assoc., Vol. 19, pp. 293-6.

Manery, J. F., I939. Electrolytes in squid blood and muscle. Fourn. Cell. Comp. Physiol., Vol. I4, pp. 365-9.

MYERs, R. G., I920. A chemical study of the blood of several invertebrate animals. fourn. Biol. Chem., Vol. 4I, pp. II9-35. 
Peters, J. P. \& van Slyke, D. D., I932. Quantitative Clinical Chemistry. Vol. II. Methods. Baltimore.

Robertson, J. D. \& WEBB, D. A., I939. The micro-estimation of sodium, potassium, calcium, magnesium, chloride, and sulphate in sea water and the body fluids of marine animals. Fourn. Exp. Biol., Vol. 16, pp. 155-77.

SheEN, R. T. \& KAHLER, H. L., I936. Direct titration of sulfates. Further studies with tetrahydroxyquinone as an internal indicator. Indust. Eng. Chem., Anal. Ed., Vol. 8, pp. 127-30.

SINGH, I., I937-8. Factors affecting the sodium, potassium and total base content of the anterior retractor of the byssus of Mytilus edulis. Fourn. Physiol., Vol. 91, pp. 398-4I2.

VAN SLYKE, D. D., I923-4. The determination of chlorides in blood and tissues. Fourn. Biol. Chem., Vol. 58, pp. 523-9.

DE WAELe, A., I930. Le sang d'Anodonta cygnea et la formation de la coquille. Mem. Acad. roy. Belg. Cl. Sci., Ser. 2, T. I0, pp. I-52 with five plates. 